\title{
A pandisability analysis? The possibilities and pitfalls of indirect disability discrimination
}

\author{
OLIVIA SMITH
}

School of Law and Governance, Dublin City University

\begin{abstract}
Introduction
$\mathrm{T}$ The prohibition of indirect race and sex discrimination has received considerable comment ever since the birth of the doctrine of disparate impact ${ }^{1}$ under Title VII of the United States' Civil Rights Act $1964 .^{2}$ Following the doctrine's adoption on this side of the Atlantic, the focus centred mainly on the interpretation and application of indirect sex discrimination at European and member state level. ${ }^{3}$ With the advent of the European Union's Framework Employment Equality Directive (hereafter the Equality Directive) ${ }^{4}$ and the Race Directive, ${ }^{5}$ the European anti-discrimination project has been extended to cover the grounds of race, religion, age, sexual orientation and disability, and there has been considerable discussion of the ramifications of this broad extension. ${ }^{6}$ However, discussion of indirect disability discrimination has been less developed, ${ }^{7}$ which reflects the situation with the pioneering Americans with Disabilities Act 1990 (hereafter, the ADA).
\end{abstract}

1 The term disparate impact is utilised in US employment discrimination law and the term indirect discrimination is generally agreed to capture the concept in European jurisprudence. Although some differences between the two doctrines remain, the terms are used interchangeably in this article.

2 Griggs v Duke Power 401 US 424 (1971). For a useful account of the uneasy place occupied by the disparate impact doctrine in US civil rights jurisprudence, see G Rutherglen, "Disparate impact, discrimination, and the essentially contested concept of equality” (2006) 74 Fordham Law Review 2313.

3 Some EU member states had introduced race discrimination legislation long in advance of EU initiatives.

4 Council Directive 2000/78/EC establishing a general framework for equal treatment in employment and occupation: OJ L303/16.

5 See Council Directive 2000/43/EC implementing the principle of equal treatment between persons irrespective of racial or ethnic origin: OJ L180/22.

6 See E Barry and C Costello (eds), Equality in Diversity: The new equality directives (Dublin: ICEL 2003) and $\mathrm{H}$ Meenan, Equality Law in an Enlarged European Union: Understanding the Article 13 Directives (Cambridge: Cambridge UP 2007).

7 There is some discussion in R Whittle, “The Framework Directive for Equal Treatment in Employment and Occupation: an analysis from a disability rights perspective" (2002) 27 European Law Review 303 and L Waddington, Implementing and Interpreting the Reasonable Accommodation Provision of the Framework Employment Directive (Brussels: EU Network of Experts on Disability Discrimination 2004). 
What accounts for this inattention to indirect disability discrimination in the literature and the case law when it generates such attention in the gender and race contexts? ${ }^{8}$ It is suggested here that it has to do with the different matrix of disability discrimination laws, within which the much-discussed duty of reasonable accommodation predominates. Despite differences in approach, the reasonable accommodation duty, which first emerged in the ADA, is common to nearly all disability discrimination statutes. Described in general terms here, it requires reasonable adjustments to employment policies, practices and structures so as to take into account the particular needs of an individual with a disability in order to accord the individual equal employment opportunities. It is viewed as core to disability discrimination law and, given its absence from other discrimination law frameworks, its presence is determinative of the "canonical" differences said to exist between disability discrimination legislation and race and sex discrimination legislation. ${ }^{10}$ While disparate impact or indirect discrimination - generally described as the unjustified differential and disadvantageous impact of "neutral" employer policies and practices on members of particular "outgroups" - has long dominated US civil rights discourse, ${ }^{11}$ the ADA's reasonable accommodation duty now attracts a comparable level of judicial and academic scrutiny. ${ }^{12}$ Leaving aside the thorny issue of disabled status, ${ }^{13}$ the vast majority of other cases under the ADA, and under its equivalents in Ireland and the UK, concern the reasonable accommodation duty, not indirect discrimination. Courts ${ }^{14}$ and commentators ${ }^{15}$ have largely ignored the ADA's disparate impact doctrine and this position has so far been replicated in many jurisdictions across the European Union. Echoing the earlier debate on disparate impact, much of the US literature has focused on the legitimacy or otherwise of the reasonable accommodation duty within the existing orthodoxy of an equality of opportunity framework. ${ }^{16}$

8 But see C Tobler, Limits and Potential of the Concept of Indirect Discrimination (Brussels: European Commission 2008) which discusses aspects of the relationship between indirect discrimination and reasonable accommodation.

9 C Jolls, "Antidiscrimination and accommodation" (2001) 115 Harvard Law Review 642.

10 Reasonable accommodation first appeared in the US Equal Employment Opportunity Commission's regulations published under Title VII in the context of religious discrimination.

11 Disparate impact law has been attacked in the US because, inter alia, of its lack of foundations in the Civil Rights Act. See Rutherglen, "Disparate impact legislation", n. 2 above.

12 Much of the debate in the US literature concerns the normative basis of anti-discrimination and accommodation principles. Various authors have argued that traditional aspects of the anti-discrimination structure are in essence accommodation mandates. See Jolls, "Anti-discrimination", n. 9 above. Cf. S Schwab and S Wilborn, "Reasonable accommodation of workplace disabilities (2003) 44 William and Mary Law Review 1197. Others argue that the duty is an example of a "legally mandated form of positive action" in favour of disabled people. See P Karlan and G Rutherglen, "Disabilities, discrimination and reasonable accommodation" (1996) 46 Duke Law Journal 1, at p. 9. Cf. M Crossley, "Reasonable accommodation as part and parcel of the antidiscrimination project" (2004) 35 Rutgers Law Journal 861.

13 A considerable number of ADA cases are dismissed on summary judgment in favour of defendants on this issue. See C Feldblum, "The definition of disability under federal anti-discrimination law: What happened? Why? And what can we do about it?" (2000) 21 Berkeley Journal of Employment and Labour Law 91. This is not as problematic an issue under the Irish legislation given the width of its definition of disability. While the Equality Directive fails to define disability, note the disappointing ECJ decision in Chacon Navas v Colectividades [2007] ICR 1.

14 In an isolated reference, the US Supreme Court in Raytheon $\mathrm{v}$ Hernandez 540 US 44, 53 (2003) recognised that "disparate impact claims are cognizable under the ADA". This comment was, however, obiter.

15 A recent exception is the discussion by M Stein and M Waterstone, "Disability, disparate impact, and class actions" (2006) 56 Duke Law Journal 861.

16 See Crossley, "Reasonable accommodation", n. 12 above, and Jolls, "Antidiscrimination", n. 9 above. 
A similar situation persists in the UK, though for somewhat different reasons: under the UK's Disability Discrimination Acts 1995-2005 (hereafter the DDA), traditional indirect discrimination claims are not justiciable due to the absence of a separate prohibition on indirect discrimination. ${ }^{17}$ Despite a number of amendments to the DDA, many driven by EU law, the UK legislature still opted against a "pure" implementation of the indirect discrimination provision. Instead, it took advantage of the provision in the Equality Directive, ${ }^{18}$ discussed below, which allows member states to choose to implement the indirect discrimination provision by means of the duty to make reasonable accommodation (adjustments). ${ }^{19}$ It has been argued that the DDA's reasonable adjustment duty embraces the indirect discrimination provision. ${ }^{20}$ This position will be interrogated below as part of the discussion of what role, if any, a specific prohibition on indirect disability discrimination has in disability discrimination protection.

A further contrast is the position under Irish law, where, despite the express inclusion of a statutory definition of indirect disability discrimination alongside the reasonable accommodation duty in the Employment Equality Acts 1998-2004 (hereafter, the EEA), the former provision, like its US counterpart, has remained under-utilised. ${ }^{21}$

There is room, therefore, for further discussion on the role and reach of the indirect disability discrimination provision and also its relationship to the reasonable accommodation duty. A recent discussion by Stein and Waterstone in the ADA context raises interesting issues for the European experience: these commentators reconsider the ADA's disparate impact doctrine in light of the original purpose of the statute. ${ }^{22}$ They highlight the doctrine's capacity to offset the individualised approach of the accommodation duty through its focus on workplace practices and norms, which disadvantage groups of disabled people. While the central premise they forward - that a disparate impact analysis usefully captures the inequalities experienced by a considerable number of disabled people - is attractive, there are a number of practical problems with its application under the current matrix of European and Irish anti-discrimination law. As will become clear below, Ireland's legislative framework provides a useful site for the discussion because it includes both indirect discrimination and reasonable accommodation in the disability context.

This article proceeds as follows. It outlines the premise and scope of the reasonable accommodation duty. While the duty is undeniably important in the scheme of disability rights, it is not without limitations. Indeed, the recognition of these limitations has

17 The DDA originally defined unlawful disability discrimination in two ways: first, less favourable treatment for a reason related to disability which was capable of justification; and second, discrimination as a failure to comply with the duty to make reasonable adjustments. The transposition of the Equality Directive ensured the inclusion of a "pure" direct discrimination provision, which is incapable of being justified.

18 Article 2(2)(b)(ii).

19 During council negotiations on the directive it was felt that the "reasonable accommodation" duty was a sufficient means of addressing indirect discrimination "since many if not all of the obstacles that arise through indirect discrimination can be removed by invoking such an obligation": Disability Discrimination Law in the EU Member States, Baseline Study (Brussels: EU Network of Independent Experts on Disability Discrimination 2004), p. 14.

20 "The functional equivalent of indirect discrimination is the section 6 duty to make reasonable adjustments.": M Connolly, Townshend-Smith on Discrimination Law: Text, cases and materials 2nd edn (London: Cavendish 2004), p. 492.

21 A review of the EEA's disability cases reveals only two (unsuccessful) cases litigated under the indirect disability discrimination provision. See O Smith, "Side-stepping equality: disability discrimination and generally accepted qualifications” (2008) 30 Dublin University Law Journal 279.

22 The preamble to the ADA implores employers to remove all "artificial, arbitrary, and unnecessary barriers" and to eliminate the "built-in headwinds" of the conventional work environment: 42 USC \$12101. 
prompted commentators to consider more closely the role of indirect discrimination in the disability context. The heuristic device of "pandisability", discussed below, has been suggested as capable of injecting renewed purpose into the ADA's disparate impact provisions. The basis of this device is outlined and then considered against the backdrop provided by the Equality Directive and Ireland's employment equality legislation.

\section{Disability discrimination and the predominance of reasonable accommodation}

Traditional employment discrimination law scholarship draws a bright line between race and sex discrimination on the one hand and disability discrimination on the other. ${ }^{23}$ The view that disability discrimination is inherently different is so prevalent that one scholar has described it as "canonical". ${ }^{24}$ The difference between the two categories of statutory schemes (race/sex and disability) can be traced to discussions around the "relevance" of such characteristics to the issue of equal employment opportunity. Basically put, the common belief now prevailing with respect to race and sex discrimination is that this phenomenon is unjust because these characteristics generally bear no relation to issues such as job capability, competence, achievement of qualifications and suitability. ${ }^{25}$ The liberal principles of individualism and meritocracy decree that persons competing for market positions should be considered objectively on the basis of their individual merits, and not on the basis of irrelevant characteristics such as race or sex. ${ }^{26}$ The process, in short, should be colour blind and gender neutral. In employment discrimination law this idea is formulated in the prohibition against direct discrimination ${ }^{27}$ across an array of grounds and with regard to various stages and aspects of the employment relationship. The basis of this provision is to prohibit "less favourable treatment" on the grounds of race, sex etc. of individuals whose circumstances are not materially different. ${ }^{28}$

On the other hand, disability and impairment retain relevance to the enquiry because, it is argued, disability is a biological reality that equates with lower productivity. ${ }^{29}$ This point presupposes that the equal treatment principle is inapplicable to disability because disabled individuals, due to their impairments, are generally not similarly situated with their nondisabled counterparts. This account can be challenged as being over-inclusive and need not sidetrack the discussion at this point. ${ }^{30}$ However, circumstances remain where the strict comparability approach alone would be insufficient to capture the nature of disability-based discrimination occurring in, for example, the interaction between an impairment and a feature of the working environment, which makes disability "relevant" to the enquiry. In such cases, the response needs to move beyond the narrowness of formal equality and

23 Stein and Waterstone, "Disability", n. 15 above, at p. 895.

24 Jolls, "Antidiscrimination", n. 9 above, at pp. 643-44.

25 One major exception is the bona fide occupational requirement where the sex of an individual may be a requirement of the job: section 25 of the EEA.

26 For a critique of the "neutrality" of these merit standards, see I M Young, Justice and the Politics of Difference (Princeton: Princeton UP 1990), ch. 7.

27 The term disparate treatment is used in the United States and generally equates to the concept of direct discrimination in European law, although differences remain in application.

28 See s. 6(1) of the EEA which sets up this approach.

29 See Schwab and Willborn, "Reasonable accommodation", n. 12 above. There are problems with this type of generalised assertion with respect to causality and, consequently, in terms of responses to disability inequality. See Crossley, "Reasonable accommodation", n. 12 above.

30 The given nature of the previous statement can be attacked. It may remain the case that a disabled person and a non-disabled person are similarly situated in the governing context, i.e. similar in terms of qualifications, experience, capability, notwithstanding the presence of an impairment, which may not require an accommodation. The problem here tends to be in respect of assumptions, fuelled by stereotyping or prejudice, that this is not the case. 
recognise that disability can be relevant to employment opportunity and, where this is the case, it ought to be taken into account accordingly. 31

However, because of dominant perceptions which equate it with incapacity, the relevance of disability is most often viewed in negative and exclusionary terms, so that the presence of an impairment resulting in different levels of functioning often forecloses employment opportunity altogether. ${ }^{32}$ For a long time disability and employment had been - and, in many cases, continue to be - viewed as mutually exclusive. ${ }^{33}$ This entrenched construction of disability in terms of personal incapacity, misfortune and economic dependence has been widely refuted by social and minority model theorists within disability discourse. ${ }^{34}$ This analysis, according to disability theorists, locates the problem of disability within the person and the contributory force of external factors, which operate to disable and exclude individuals with impairments are ignored. In short, the biological account of disability is incomplete and, therefore, challengeable. There are obvious parallels between this analysis and formerly held dominant social conventions that viewed women as less capable than men, and race as a biological absolute. ${ }^{35}$ While such (widespread, at least) views of sex and race have, in the main, been left behind, they have been much more difficult to dislodge in the disability context. Courts and many commentators retain considerable difficulty in seeing disability as anything other than an identifiable and verifiable medical problem of the individual. ${ }^{36}$

What is clear from the above account is that any disability equality initiative predicated solely on the equal treatment principle would be an impoverished one. Developments at the level of equality theory and within disability discourse have combined to deconstruct both the "equality as sameness" paradigm and the "neutral" forces that view disability as an individual problem, which explain and legitimate non-participation in the labour market and other aspects of social life. The particularities of the disability issue have helped contribute to the development of more substantive equality norms. In this context the focus has rested almost exclusively on the individual reasonable accommodation duty.

Article 5 of the Equality Directive outlines the rationale of this development: it equates the equal treatment of persons with disabilities with the provision of "reasonable accommodation" and

[t]his means that employers shall take appropriate measures, where needed in a particular case, to enable a person with a disability to have access to, participate in, or advance in employment or to undergo training, unless such measures would impose a disproportionate burden on the employer.

31 G Quinn, "Rethinking the place in difference in civil society - the role of anti-discrimination law in the next century" in R Byrne and W Duncan (eds), Developments in Discrimination Law in Ireland and Europe (Dublin: ICEL 1997), p. 64, at p. 77.

32 This statement is not intended to exclude those with impairments with little functional impact (e.g. physical disfigurements) but who, nevertheless, endure exclusion due to stigma.

33 See A Silvers, "Formal justice" in A Silvers, D Wasserman and M B Mahowald, Disability, Differences, Discrimination: Perspectives on justice in bioethics and public policy (Lanham: Rowman and Littlefield Publishers 1998), p. 13.

34 See M Oliver, The Politics of Disablement (London: Macmillan 1990). For discussion of disability as a minority group issue, see H Hahn, "Anti-discrimination laws and social research on disability: the minority group perspective" (1996) 14 Behavioral Sciences and Law 41.

35 Stein and Waterstone, "Disability", n. 15 above, at pp. 895-6 for discussion.

36 See comments of the Irish Supreme Court in Re Article 26 and the Employment Equality Bill 1996 [1997] 3 IR 321, at p. 367. 
The idea behind the duty is to tackle established workplace and social norms, which erect barriers to the equal employment opportunities of disabled people. ${ }^{37}$ The response, therefore, requires alteration of the work environment and/or practices, where reasonable, in order to accommodate individuals across a wider range of functioning levels. ${ }^{38}$

Notwithstanding the real significance of reasonable accommodation as a disability equality initiative, it is constrained by factors internal to its statutory design (such as the limits inherent in the qualifier "disproportionate burden") and by factors pertinent to discrimination law enforcement more generally. Despite the assumed group objectives attributed to legal rights at the policy level, at the operational level, the duty is highly individualistic in its assessment of the kind of accommodation necessary to achieve the participatory goals of a particular disabled person in the particular workplace at issue. In this sense, reasonable accommodation, where required, "always involves an individual assessment and a tailored individual solution". 39 The group dimension appears to be ad hoc at best: in the strongest, almost altruistic sense, the duty may be described as anticipatory only if it inspires employers to think about accommodation requirements in advance and the alteration of practices and policies so as to be as inclusive as possible to all. In this sense, there is some equivalence between the accommodation duty and the principles of Universal Design. ${ }^{40}$ In practical terms, the duty does not operate in this manner in many statutes; for example, under the UK's DDA, the duty only becomes operable upon an employee or applicant specifically making an accommodation request. ${ }^{41}$ Thereafter, "an interactive dialogue" between the parties should, ideally, take place. The more realistic perspective is that employers overlook the underlying broader objectives attributed to the duty and react only when faced with an accommodation request from a protected individual. On this view, the basis of the duty, therefore, is to accommodate individuals into existing structures without systematically challenging the structures, institutions and norms on which they depend. Further, the enforcement mechanisms institutionalised within discrimination law support this analysis. If a complainant successfully pursues a failure to accommodate claim against his or her employer, where the suggested accommodation imposes no disproportionate burden, then the specific workplace policy is, in theory at least, altered for that individual. There is little to no discussion whether other individuals with disabilities beyond the complainant may benefit by the accommodation duty. ${ }^{42}$ This atomistic, individualistic conception of the accommodation duty, combined with the longstanding problematic enforcement strategies of discrimination law, limits its transformative effect. ${ }^{43}$ However, as is discussed below, the assumed inevitability of individual relief under the accommodation duty may be overstated as "[m]any requests for accommodation dealing

37 For a robust critique of the duty, see S Day and G Brodsky, "The duty to accommodate: who will benefit?" (1996) 75 Canadian Bar Review 433.

38 It was expected that the duty would help tackle the consistent and endemically low employment rate of disabled people. In Ireland in $2004,37 \%$ of people of working age with a disability/longstanding health problem were in work, compared to $67 \%$ of other working age adults: National Disability Authority, A Strategy of Engagement - Towards a comprehensive employment strategy for people with disabilities (Dublin: NDA 2007), at p. 3.

39 Waddington, Implementing and Interpreting, n. 7 above, at p. 8.

40 See text to n. 49 below.

41 This presupposes that employees/job applicants are aware of the duty and is problematic because of reported low levels of awareness of equality rights: ESRI/Equality Authority, The Experience of Discrimination in Ireland: Analysis of the QNHS Equality Module (Dublin: ESRI 2008).

42 Stein and Waterstone, "Disability", n. 15 above, at p. 899.

43 See generally, Brodsky and Day, "The duty to accommodate", n. 37 above. 
with physical accessibility and environmental design, for instance, can be commonly remedied by use of universal design principles". 44

Research in the US demonstrates that the reasonable accommodation duty has not dramatically transformed the employment situation of disabled people. ${ }^{45}$ Significant reductions in the unemployment rates of disabled people in Ireland do not appear to be emerging despite the existence of disability equality provisions for near on a decade. ${ }^{46}$ How useful the duty is to job applicants with disabilities seeking access to the labour market remains unclear. A clear pattern appears to be emerging from the body of caselaw generated under the Irish legislation: most complainants raising the reasonable accommodation duty are job incumbents, or dismissed former employees, and not job applicants. It seems far easier for a job incumbent to rely on the reasonable accommodation duty than it is for a job applicant. ${ }^{47}$ The system relies on an individual complainant perceiving his or her situation in litigation terms, which, if successful, may result (more often than not) in an award of compensation for discriminatory dismissal or discriminatory treatment consequent upon a failure on the part of respondents to consider their obligations under the reasonable accommodation duty. There are only a few examples in the caselaw of courses of action ordered under the accommodation duty which allow an individual to continue in employment. ${ }^{48}$ For the most part, litigation reveals that the duty often boils down to a consideration of the legitimacy of an employer's actions: either to accommodate a particular individual employee or not, and whether the decision taken was legitimate given the parameters of the duty as set out in the particular statute. Where an accommodation is requested by a disabled individual and is refused, the status quo remains. ${ }^{49}$

44 Stein and Waterstone, "Disability", n. 15 above, at p. 903. Universal Design is an architectural concept and its goal is to design products that are usable by all people, to the greatest extent possible, without the need for adaptation or special design. Cited in text to n. 143 at p. 893. See Center for Universal Design, Principles of Universal Design at www.design.ncsu.edu/cud/about_ud/udprinciples.htm (last accessed 6 October 2009).

45 D Stapelton and R Burkhauser, The Decline in Employment of People with Disabilities: A policy purzle (Lanham: Rowman \& Littlefield Publishers 1998).

46 In the 30-month period between the two Central Statistics Office surveys on disability in 2002 and 2005, the employment rate for people with a disability fell from $40.1 \%$ to $37.1 \%$ despite overall employment growth of $5.6 \%$ over the period: NDA, A Strategy, n. 38 above, "Executive summary", p. 3. It is simplistic to assert that the introduction of disability equality law is a sufficient means of effecting the integration of disabled people into employment. Other issues remain pertinent and include: access to education; the issue of disability benefits, in particular the "benefit trap"; working time issues; health issues; not forgetting the prevailing economic climate. See ibid. and M Weber, "Beyond the Americans with Disabilities Act: a national employment policy for people with disabilities" (1998) 46 Buffalo Law Review 123.

47 See the narratives discussed in M Russell, Beyond Ramps: Disability at the end of the social contract (Monroe: Common Courage Press 1998), p. 118.

48 In Feore $\mathrm{v}$ Alzheimer Society of Ireland DEC-E2006-101, the remedy ordered by the Equality Tribunal included the offer of the position the complainant would have held had she not been absent from work on sick leave. Most failure to provide reasonable accommodation claims have arisen as a consequence of discriminatory dismissals and the remedy awarded is generally compensation, although reinstatement and re-engagement are options available to the tribunal under the Acts.

49 In A Computer Component Company v A Worker ED/OO/8, the complainant was sacked due to the apparent incompatibility between her impairment and a rather infrequent duty of her position - to operate a particular machine. For breach of the duty, which would have excused the complainant from using this machine, she was awarded compensation and not the job. This occurrence is prevalent across the caselaw. 
Due to the predominance of these individualistic issues, a group dimension, the oftenattributed benefit of indirect discrimination ${ }^{50}$ seems less obvious in respect of the accommodation duty. As Stein and Waterstone point out

Much heavy weather is made of the heterogeneity of disability with the result that, rather than being viewed as systematically excluded by the environment, disability is held to be the by-product of individual workers not fitting into particular workplace circumstances. Consequently, assertions of disability discrimination have been closeted into a narrow category that examines the reasonableness of a particular accommodation to a single individual rather than questioning the larger issue of whether a hostile workplace environment was constructed that excluded employees with disabilities. 51

These commentators reference a combination of factors which explain the reluctance to formulise failure to accommodate claims under a theory of disparate impact. One prominent reason is that the failure to accommodate claim is viewed as a stand-alone substitute for disparate impact litigation. A second reason for the US federal courts' reluctance to engage with disparate impact under the ADA is the belief that Title I's statutory basis of disparate impact is less clear than that which exists under Title VII of the Civil Rights Act. As shall be discussed below, both of these explanations hold little weight in the Irish context given the EEA's express inclusion of a stand alone indirect disability discrimination provision, alongside the reasonable accommodation duty. It is submitted that factors relating to the "difference" of disability discrimination, difficulties in surmounting the individual, as opposed to group, effects of the experience of disability exclusion, alongside specifics internal to the statutory design of the indirect discrimination, account for the under-use of the indirect disability discrimination provision.

\section{The nature of the reasonable accommodation duty}

Some discussion has taken place on the nature of the duty as a positive or negative right: in other words, whether it is a positive duty placed on employers, which implies a right to an accommodation, or a negative provision where a refusal of an accommodation amounts to discrimination. This issue has been discussed in detail by Waddington. ${ }^{52}$ The angle of interest for this discussion is the consequence of a failure to accommodate and whether this amounts to actionable discrimination of a particular kind, whether direct, indirect or a socalled "third way".53 This reveals the fuzzy relationship between the orthodox constructions of discrimination law (namely, direct and indirect) and the reasonable accommodation duty. In EC law, Article 5 of the Equality Directive expressly provides a relationship between the principle of equal treatment and the duty to provide reasonable accommodation. However, the directive does not explicitly call the denial of reasonable

50 The group benefits of indirect discrimination have been questioned: Schiek argues that "group disadvantage has always been the starting point for indirect discrimination, but it has never established group rights": D Schiek, "Indirect discrimination" in D Schiek, L Waddington and M Bell (eds), Cases, Materials and Text on National, Supranational and International Non-Discrimination Law (Oxford: Hart Publishing 2007), p. 323, at p. 330 On this point, there is a real distinction between the doctrinal path suggested by Stein and Waterhouse, discussed below, and its applicability to the European context, which is the absence of a tradition of class action litigation in European discrimination law.

51 Stein and Waterstone, "Disability", n. 15 above, at p. 897.

52 See Waddington, Implementing and Interpreting, n. 7 above, at pp. 41-4.

53 See L Waddington and A Hendricks, "The expanding concept of employment discrimination in Europe: from direct and indirect discrimination to 'reasonable accommodation' discrimination” (2002) 18 International Journal of Comparative Labour Law and Industrial Relations 402, who argue that a failure to provide a "reasonable accommodation" is a form of discrimination sui generis. 
accommodation a form of discrimination. ${ }^{54}$ Tobler argues that the directive treats the duty as "a specific obligation of the employer, to which corresponds a specific right on the side of the employee with a disability" and she deems it unnecessary and unadvisable to label the refusal to provide reasonable accommodation "indirect discrimination". 55 Yet, as is discussed below, there is a link in EC law between indirect discrimination and reasonable accommodation under Article 2(2)(b)(ii).

In Irish domestic law the status of the EEA's reasonable accommodation was not originally clarified. Not surprisingly, it has yet to be considered whether a failure to accommodate claim can be analysed in disparate impact terms. In its early stages, despite no explicit connection between the statute's definitions of discrimination (both direct or indirect), the interpreting tribunals had mainly viewed failure to accommodate cases as an independent limb of actionable discrimination, without characterising it as either direct or indirect. A purposive interpretation of the statute clearly demanded this approach because the statutory provisions dealing with remedies are dependent on a finding of "discrimination". 56 However, in $A$ Worker $(M r O)$ v An Employer (No 1), 57 the Labour Court expressly rejected the proposition that the EEA's original accommodation duty amounted to a freestanding right: that is, that an individual has a right to a reasonable accommodation where the burden on the employer did not give rise to any extra-nominal costs. ${ }^{58}$

In section 6(1), discrimination is defined in the traditional manner of less favourable treatment on the basis of any of the protected grounds, including disability. Indirect discrimination is provided for later in the statute. ${ }^{59}$ However, section $16(1)$ provides a defence to employers by providing that the Act does not require employers to recruit, promote, retain or train an individual for a position if that person is not fully competent and fully capable of undertaking the duties of a position. However, the section 16(1) defence is itself qualified by section 16(3), which set out, in a rather convoluted manner, the original reasonable accommodation provision: in essence it provides that a person with a disability shall be considered fully competent for a position if with special treatment or assistance they would be fully capable for the position and an employer is required to do all that is reasonable to accommodate the person by providing such special treatment or facilities.

In $A$ Worker $(M r O)$ v $A n$ Employer (No 1), the Labour Court interpreted the scope of the reasonable accommodation duty under the 1998 Act strictly within the confines of section 16. It noted that notwithstanding section 6(1), section 16(1) allows an employer to treat a disabled person less favourably than others. This defence is available where a disabled person is not fully capable of carrying out "all the duties attached to the job for which they applied". However, the employer defence is, in turn, qualified by subsection 3, outlined above, which imposes a duty on employers, where reasonable, to provide such special treatment/facilities so as to render the disabled person competent and capable of the job required of them. This link between section 16(3) and section 16(1), according to the Labour Court, made it clear that the reasonable accommodation duty did not found "an independent cause of action for an employer's failure to provide special treatment or

54 The definition of discrimination under Art. 2 of the UN Convention on the Rights of Persons with Disabilities (CRPD) expressly includes the denial of reasonable accommodation.

55 Tobler, Limits and Potential, n. 8 above, at Part IV, para. 5.

56 S. 77 of the Act as amended specifically grants a person who claims "to have been discriminated against by another in contravention of this Act" the right to seek redress in various fora: s. 77(1)(a).

57 [2005] ELR 132.

58 This was the original standard set out in the 1998 Act before the Equality Act 2004 altered it to the European standard of "disproportionate burden".

59 See ss 22 and 31 of the EEA 1998-2004. 
facilities". Further support for this position, according to the Labour Court, is available because no part of the Act defined discrimination as including a failure to fulfil the reasonable accommodation duty. Thus, prior to the amendments introduced by the Equality Act 2004, the only way the duty to accommodate became operative was as an antidote to an employer's reliance on the defence in section 16(1) allowing it to treat a disabled person less favourably. Consequently, where the employer did not seek to rely on section 16(1), the duty had no application. The amendments to the 1998 Act, brought in by the Equality Act 2004, do appear to allow a freestanding cause of action. This is because the language in the amending clause places an independent duty (unlinked to section 16(1)) on employers to provide reasonable accommodation to disabled workers and applicants. ${ }^{60}$

Despite this positive development, the amendments do not expressly link the failure to accommodate with the possibility of an indirect discrimination claim - but neither do they expressly forbid this approach. This ambiguity is not unique to the Irish statutory framework and it permeates others, such as the equivalent provision under the ADA. One reaction to the perceived limitations of the duty has been an increasing inquisition into its purpose and effectiveness. As referred to already above, a number of studies in the United States ${ }^{61}$ demonstrate that the ADA has failed to challenge the in-built headwinds facing disabled people accessing employment. There are, of course, many contributory factors, not all of which can be attributed to the "failure" of discrimination law protections. However, increasingly, the structural foundations of the ADA's reasonable accommodation duty are under scrutiny from which a "backlash" against the federally driven disability provisions has emerged. ${ }^{62}$ Simultaneously, however, this can create room for discussion of a more constructive nature: in particular, it leaves space to consider the role of disparate impact in the disability context and its interaction with or influence on the reasonable accommodation duty.

The next section goes on to outline the genesis of the indirect discrimination doctrine and, at a general level, considers the possibilities for the provision in the disability context. Given that one of the key ideas behind indirect discrimination has been to expose the adverse effect of putative neutral practices on groups, the discussion considers whether the doctrine can offset the individualised focus of the accommodation duty.

\section{The development of indirect discrimination}

Within equality theory the traditional construct of the equal treatment principle has long invited a range of criticisms. ${ }^{63}$ For one, because the principle of equal treatment concentrates on excising differential treatment stemming from racial prejudice and gender stereotyping, it is predicated on a version of equality which generally accepts the given backdrop of existing labour frameworks and other institutional environments and does not demand that they are radically restructured. Thus, even if unequal treatment was successfully tackled through the prohibition on direct discrimination, powerful and established institutional and societal arrangements maintain existing distributive patterns and hierarchies, which benefit certain groups at the expense of others. ${ }^{64}$ As Collins continues, these institutional arrangements are both formal and informal; for example,

60 S. 16(3)(b) of the EEA 1998-2004.

61 See R Colker, “The Americans with Disabilities Act: a windfall for defendants” (1999) 34 Harvard Civil RightsCivil Liberties Review 99.

62 See L Hamilton Krieger, "Backlash against the ADA: interdisciplinary perspectives and implications for social justice strategies" (2001) 21 Berkeley Journal of Employment and Labor Law 1.

63 See N Lacey, "From individual to group? A feminist analysis of the limits of anti-discrimination legislation" in Unspeakable Subjects: Feminist essays in legal and social theory (Oxford: Hart Publishing 1998), at p. 19.

64 H Collins, "Discrimination, equality and social inclusion" (2003) 66 Modern Law Review 16, at p. 30. 
formal rules requiring full-time work for entry to pension schemes impact adversely on part-time workers who are disproportionately female because of more informal social norms that see women taking primary responsibility for caring obligations. ${ }^{65}$ Likewise, fulltime work norms can disproportionately impact on those disabled people unable to commit to full-time work due to medical reasons. Minimum occupational requirements such as formal education qualifications - for example, state examinations - can impact adversely on certain disabled people denied mainstream education because of accepted social norms that deem many disabled people as uneducable.

Indirect discrimination, it is argued, purports to capture the systemic differential impact which longstanding, assumed ordinary and "neutral" practices can have on different groups. Recognised by the US Supreme Court in Griggs v Duke Power Company, ${ }^{66}$ it was held that Title VII of the Civil Rights Act 1964

... proscribes not only overt discrimination but also practices that are fair in form, but discriminatory in operation. The touchstone is business necessity. If an employment practice ... cannot be shown to be related to job performance, the practice is prohibited. ${ }^{67}$

The first recognition of the Griggs principle on this side of the Atlantic was in the UK's Sex Discrimination Act 1975. At the European level, indirect sex discrimination was eventually recognised in community law through judicial interpretation of Article 141 of the EC Treaty. ${ }^{68}$ The European Court of Justice jurisprudence was codified in 1997 in the Burden of Proof Directive in cases of sex discrimination. ${ }^{69}$ This definition has recently been reformulated in the Amended Equal Treatment Directive. ${ }^{70}$ A further definition of indirect discrimination applicable to the newer grounds is set out in the Framework Employment Equality Directive.

The major strength of indirect discrimination is that it conceptualises discrimination as involving more than intentional, episodic or individualised wrongdoing. ${ }^{71}$ It attempts to expose the discriminatory by-product of so-called neutral practices and it requires employers either to justify the continued operation of practices which deny individuals from particular groups equal employment opportunities or, where justification cannot be made out, to desist from their use. ${ }^{72}$ The doctrine's approach would, prima facie, suggest it is underpinned by a more substantive conception of equality as compared with the individualistic modification of practices for a single employee under the accommodation analysis. However, the translation of these ideas into law has been "extraordinarily problematic". ${ }^{73}$ These difficulties are multifaceted and include issues which have long plagued the gender equality agenda and which are not developed here, such as: the differing

65 Collins, "Discrimination", n. 64 above. This policy was originally challenged as indirect sex discrimination prior to the introduction of Council Directive 97/81/EC Framework Agreement on Part Time Work OJ L 14, 20.1.1998.

66 Griggs v Duke Power 401 US 424 (1971).

67 Ibid., at p. 431.

68 Bilka Kaufhaus v Weber von Hartz [1986] ECR 1607.

69 Art. 2(2) Directive $97 / 80 / \mathrm{EC}$ on the burden of proof in cases of discrimination based on sex [1998] OJ L14/6.

70 Directive 2002/73, OJ [2002] L269/15: Art. 2(2).

71 C Gooding, Disabling Laws, Enabling Acts: Disability rights in Britain and America (London: Pluto Press 1994) pp. 38-9.

72 "The standard judicial remedy in a Title VII disparate impact case requires the employer to change the policy or standard for everyone, not just the protected group.": Schwab and Willborn, "Reasonable accommodation", n. 12 above, at p. 1238.

73 A McColgan, Discrimination Law: Text, cases and materials 2nd edn (Oxford: Hart Publishing 2005), p. 76. 
definitions of indirect discrimination; ${ }^{74}$ the constant amendment to the definitions; proof of the constituent elements of disparate impact, including judicial wrangling over the tests utilised to prove acceptable degrees of disparate impact; ${ }^{75}$ the use and (non)-availability of statistical evidence; ${ }^{76}$ and the breadth of the justification defence. Further, the group effects of indirect discrimination have also been queried, in particular, the extent to which the principle has inclusionary aspects which oblige employers to take into account and accommodate the needs of individuals with certain characteristics. Consequently, there has been a measure of disappointment with the indirect discrimination doctrine, which Schiek attributes to

overburdening the prohibition of indirect discrimination with the expectations of achieving all the substantive aims of discrimination law and policy at large, although indirect discrimination law is only a small part of equality law and policy. 77

\section{Background to indirect disability discrimination}

According to one US federal judge, the disparate impact doctrine emerged in response to "... situations where, through inertia or insensitivity, companies were following policies that gratuitously ... excluded black or female workers from equal employment opportunities". 78 In the US neither judges nor scholars have felt comfortable replacing "black or female workers" with "disabled workers". ${ }^{79}$ Yet the ADA includes statutory provisions consistent with the theory of disparate impact as recognised under Title VII. ${ }^{80}$ Further, both European and member state legislatures expressly included a definition specific to the disability ground, although the EC adopts an alternate optional approach in Article 2(2)(b)(ii). Presumably, those legislative bodies assumed that the doctrine had some role to play in addressing disability discrimination so as to merit its inclusion in the statutory framework. Put another way, the express inclusion of the indirect discrimination doctrine gives rise to a presumption that the inequality endured by disabled people can manifest itself in a manner conducive to a disparate impact analysis. In fact, the traditional understanding of the way ordinary and commonplace practices, structures and institutional arrangements indirectly and adversely impact on members of particular groups seems a very cogent way of explaining the type of disadvantageous exclusion endured by disabled people. The well-documented experiences that disabled people have of discrimination and inequality are less often direct. Disability inequality is often the product of practices and procedures that have been designed with the needs and requirements of the average, able-bodied individual in mind. ${ }^{81}$ For example,

74 Ireland's EEA originally contained four definitions of indirect discrimination, delineated by pay, other aspects of the employment relationship, gender and the other eight protected grounds.

75 On the issue of adverse impact, see R v Secretary of State for Employment, ex parte Seymour Smith and Perez. [1999] ECR 623 (ECJ) and [2000] 1 All ER 857 (HL).

76 Ibid.

77 See Schiek, "Indirect discrimination", n. 50 above, at p. 332.

78 Finnegan v Transworld Airways Inc. 967 F2d 1161, 1164 (7th Cir 1992).

79 Stein and Waterstone, "Disability", n. 15 above, at p. 886.

80 No single provision under the ADA deals with disparate impact. Rather, there are a number of provisions consistent with disparate impact theory developed under Title VII. For example, the ADA prohibits employers from "utilising standards, criteria or methods of administration . . . that have the effect of discriminating on the basis of disability". It also prohibits employers from using qualification standards, tests or other selection criteria that screen out or tend to screen out disabled people unless the standard, test or other selection criteria is shown to be "job-related ... and ... consistent with business necessity". 
neutral rules which permit access to benefits based on continuity of service can exclude individuals who take medical leave; rules which exclude part-time work opportunities can exclude disabled people who traditionally have greater health needs; rules which set break times at pre-designed slots can affect individuals with medical requirements; rules which require communications to be effected in a particular manner can exclude individuals with cognitive or sensory impairments. Whether these are issues of accommodation or disparate impact and the effect of this characterisation is explored below.

Given the prima facie utility of indirect discrimination principles to the disability ground, it is necessary to consider what drives this reluctance to conceptualise disabilitybased discrimination in disparate impact terms. Perhaps the most commonly expressed reason for this limited consideration of the disparate impact doctrine is the lack of homogeneity among disabled people as a class. The heterogeneous nature of disability is thought to render a disparate impact analysis less potent and the individualisation of disability as a personal issue, particularly in employment litigation, is critical to this argument. For example, Rutherglen attributes the rarity of ADA class actions to "the predominance of individual issues, such as the nature and extent of a person's disability and the cost of accommodations". ${ }^{82}$ Unlike sex discrimination cases, where assumptions are generally made (often leading to charges of essentialism) about the impact of particular policies or practices on women as a class, the disability category, it is argued, is simply too diffuse to ground a disparate impact analysis.

It has been suggested, however, that this barrier to disability indirect discrimination can be surmounted. Borrowing from the term "panethnicity" utilised in US class action suits, Stein and Waterstone develop a similar concept of "pandisability" in response to the heterogeneous issue. The notion of panethnicity was key to early Title VII disparate impact and class action litigation in the United States; it describes "the heuristic processes through which ethnic minority groups that might internally consider themselves heterogeneous are externally perceived by the non-group majority as homogeneous". 83 Panethnicity involves the grouping together of different nationalities/ethnicities under the banners of AfricanAmericans or Asian-Americans in order to allow diffuse groups to pursue race-based disparate impact litigation. ${ }^{84}$ Instead of viewing the perceived heterogeneity of the disability class as a barrier to disparate impact analysis, the pandisability approach sees disability as a unifier: it is a minority group issue which allows individuals with diverse impairments to be treated alike for group identification purposes. In this way, wheelchair users, individuals with learning disabilities, individuals with cognitive impairments, despite differences at the bio-medical level, can be categorised as forming a class on a more fundamental level because of their shared experiences of exclusion, animus and prejudice. There are clear links between the pandisability concept and the social model of disability

81 Brodsky and Day have queried this account of the neutrality of ordinary standards and common practices as unintentional. The whole scale exclusion of disabled people from mainstream social, economic and cultural practices is a systematic phenomenon that can hardly be described as unintentional or as a simple by-product of development: "Duty to accommodate", n. 37 above, at p. 458.

82 Rutherglen, "Disparate impact", n. 2 above, at p. 2319, at n. 43: "the few disparate impact claims under the Americans with Disabilities Act of 1990 that are likely to be successful concern denial of access to government services or public accommodations under Titles II and III". See Sunrise Dev Inc v Town of Huntingdon 62 F Supp 2d 762, 766-7 (EDNY 1999).

83 Stein and Waterstone, "Disability", n. 15 above, at p. 870, relying on Y Le Espiritu, Asian American Panethnicity: Bridging institutions and identities (Philadelphia: Temple UP 1992).

84 Courts in the United States have allowed groups such as Korean, Japanese and Chinese Americans to be represented under the banner of Asian-Americans in class action litigation. This approach has also been utilised by Latinos/Hispanics. 
within disability discourse: antecedents of the pandisability concept can be traced to basic social model theorising where disability is viewed as a form of social oppression imposed on individuals with impairments. It is the social consequences of disability, as expressed in the commonality of prejudicial experience, which in turn reinforces disparate individuals' membership in the disability classification. ${ }^{85}$ Viewed in this way differences in impairments and degrees of functional impact can be put to one side. This development of pandisability is key to the analysis of the failure to accommodate limb of disability discrimination law in disparate impact terms and is considered below.

\section{A disparate impact analysis of failure to accommodate claims}

The issue for discussion here is whether a failure to accommodate an individual with a disability can ground a cause of action of indirect disability discrimination. In other words, whether a neutral provision or practice which places persons with a disability at a particular disadvantage and which an employer has not offset by way of reasonable accommodation can be analysed in indirect discrimination terms. This question is interesting because of the responses generated following each cause of action. Under the traditional reasonable accommodation duty (where successful), the response requires the adjustment of a policy/practice in favour of a single individual. Otherwise, the policy or practice concerned remains untouched. However, the response in the case of a policy found to have a disparate impact would be striking down or adjusting the policy for all members of the group: otherwise there is a risk of further litigation from members of the same class. ${ }^{86}$

There is some discussion in the literature on the similarities between the two types of statutory protection. One strand of the discussion of the accommodation duty in the US has arisen from the need to stabilise it within the boundaries of equality of opportunity theory in order to insulate it from judicial attack and public and academic backlash. ${ }^{87}$ To this end, Christine Jolls' seminal work demonstrates the similarities - in terms of doctrinal reach and practical response - between the ADA's accommodation mandate and the disparate impact doctrine under Title VII. ${ }^{88}$ Jolls' analysis of several cases under orthodox anti-discrimination law shows that a successful disparate impact suit involves the alteration of pre-existing employment practices in favour of the protected group: she argues that "important aspects of disparate impact liability are in fact accommodation requirements". 89 In other words, an accommodation type of remedy was provided in many Title VII disparate impact cases. The main success of disparate impact in the US has been to tackle the use of job specifications that are unrelated to job performance but which hinder the uptake of employment opportunities and benefits on the part of women and ethnic minorities. For example, Jolls has highlighted caselaw which has successfully attacked the disparate impact of "neutral" grooming rules - no-beard rules on black men, job selection criteria, including standardised tests, on African-Americans generally, rules excluding the

85 Stein and Waterstone, "Disability", n. 15 above, at p. 900.

86 One objection to the disparate impact analysis is the need to alter the practice in different ways due to the differing impact of the practice on persons with different types of disabilities. However, this approach raises the issue of remedy, as opposed to the actual cause of action. In the history of class action litigation in the US, where disparate classes united to challenge the effects of particular employment practices, cases were not hindered by the fact of diverse remedies being provided, where successful.

87 In Board of Trustees of the University of Alabama v Garrett 531 US 356 (2001), the Supreme Court held that the states are not subject to private suits for monetary damages under Title I of the ADA. See also, Hamilton Krieger, "Backlash against the ADA", n. 62 above.

88 See generally, Jolls, "Anti-discrimination", n. 9 above.

89 Ibid., at p. 651. 
use of leave and their effect on pregnant women, and English-only rules for their effect on ethnic minorities. ${ }^{90}$

What Jolls omits to consider is whether the ADA's failure to accommodate cause of action can itself be subject to a similar disparate impact analysis. Stein and Waterstone go on to present the possibilities opened up by a disparate impact analysis under Title I of the ADA. This analysis, they argue, has the capacity to offset the hitherto individualised focus of the reasonable accommodation duty by pointing to employer practices and procedures that disproportionately affect groups of disabled people. In this sense, litigation moves beyond a consideration as to whether a particular reasonable accommodation should have been provided and considers whether the workplace norms adopted by the employer adversely impact other disabled individuals beyond the claimant. These commentators then adapt Joll's Title VII disparate impact scenarios with accommodation remedies to ADA disparate impact examples, such as:

(1) rules on the use of physically inaccessible venues when alternative accessible venues are available (such as placing a workstation up a flight of stairs where it is dangerous for someone with a balance disorder);

(2) job selection criteria that tend to exclude people with disabilities (e.g. quadriplegic bank teller to lift boxes, or standardised testing or written tests that severely dyslexic persons may not be able to perceive);

(3) rules that require the use of specific systems that adversely effect individuals using alternative formats (e.g. Braille, large print etc.);

(4) refusals of leave time/alternative work venues. ${ }^{91}$

They argue that applying basic disparate impact theory to the accommodation duty would enable people with disabilities to challenge the type of "neutral" workplace policies and practices commonly challenged under Title VII. It may be that the consequence of a successful disparate impact analysis will be the alteration of the practice, criterion or provision that gives rise to the disparate impact, where it remains unjustifiable; this has the advantage of providing a remedy which is inclusive and redistributive as opposed to compensatory and exclusive. The discussion below considers whether these arguments translate to the European and Irish practice of indirect discrimination and reasonable accommodation.

\section{From theory to practice: the statutory design of indirect disability discrimination}

\section{THE EEA AND INDIRECT DISCRIMINATION}

Section 31 of the EEA, as amended by the Equality Act 2004, sets out the definition of indirect discrimination applicable to the non-gender grounds. This is a technical amending provision, the net effect of which is to apply the definition of indirect discrimination that operates in respect of the gender ground to the other eight grounds. The definition of indirect discrimination applicable to disability reads:

Indirect discrimination occurs where an apparently neutral provision puts persons of of a particular disability at a particular disadvantage in respect

90 Jolls, "Anti-discrimination", n. 9 above, at pp. 652-66.

91 Stein and Waterstone, "Disability", n. 15 above, at pp. 915-16. 
of any matter other than remuneration compared with other employees of their employer. ${ }^{92}$

Where this paragraph is satisfied, the employer is deemed to be discriminating against the claimants unless the provision is objectively justified by a legitimate aim and the means of "achieving that aim are appropriate and necessary". 93

On its face, the definition may attempt to guard against some of the obvious disadvantages faced by many disabled people within a society predicated on ostensibly neutral yet exclusionary norms. For example, minimum educational requirements are demanded on the assumption that educational opportunity is generally available to all unnecessary educational qualifications have long been recognised as capable of giving rise to disparate impact; ${ }^{94}$ full-time work norms are demanded because historically this has been a cornerstone of capitalist production and it places "equal" demands on all constituents of society. However, many neutral policies, procedures and practices of the working environment have differential effects on groups of individuals who depart from the fulltime, face-time norm of the paradigm worker. ${ }^{95}$ Much use has been made of the indirect discrimination principle in the gender context where putative neutral policies such as height and weight requirements, ${ }^{96}$ unnecessary length of service/continuous service requirements ${ }^{97}$ and full-time work norms ${ }^{98}$ have been found to bear more heavily on women, particularly older women and women with caring responsibilities. However, there have been numerous gaps in the coverage of indirect sex discrimination which has lead to a reassessment of the principle's potential to transform established workplace and social norms. ${ }^{99}$ Many of these issues appear to repeat themselves in the disability context. Further, there are aspects to the definition and further provisions within the Act which appear to threaten the operability of the provision in the expansive manner contemplated above. ${ }^{100}$

It is not entirely clear whether the current definition can facilitate a pandisability analysis of disparate impact claims as developed by Stein and Waterstone in the US context. The view expressed here is merely tentative and is based on a combination of factors that influence the construction of disability in assessing equality claims. ${ }^{101}$ Many commentators have taken the view that "reasonable accommodation" discrimination is different because the

92 S. 31(1)(a) of the EEA as amended. The definition of indirect discrimination in the Equality Directive includes contingent harm, i.e. it covers the possibility of adverse impact as opposed to the actual occurrence of adverse impact. The EEA definition does not reflect this aspect of the directive. See E Ellis, EU Anti-Discrimination Law (Oxford: OUP 2005), pp. 91-4.

93 S. 31(1)(b) of the EEA 1998-2004. A similar provision extends the indirect discrimination protection to pay practices, but this is subject to s. 35(1).

94 See Griggs v Duke Power 401 US 424 (1971).

95 See M Travis, "Recapturing the transformative potential of employment discrimination law" (2005) 62 Washington and Lee Law Review 3.

96 Allcock v Chief Constable Hampshire Constabulary ET case no 3101524/97.

97 Falkirk Council v Whyte [1997] IRLR 560.

98 Inoue $\mathrm{v}$ NBK Designs Ltd [2003] ELR 98.

99 See C Barnard and B Hepple, "Substantive equality" (2000) 59 Cambridge Law Journal 562 and Tobler, Limits and Potential, n. 8 above, at V.5.

100 Specifically, s. 36 of the EEA 1998-2004. For discussion, see Smith, "Side-stepping equality", n. 21 above.

101 For a discussion of the effect of textualism as the dominant mode of interpretation and its influence on disability rights, see W Parmet, "Plain meaning and mitigating measures: judicial interpretations of the meaning of disability" (2000) 21 Berkeley Journal of Employment and Labor Law 53. 
disadvantage is not necessarily experienced by all or most members of a particular group, but is . . . experienced on the individual level, depending on both individual and environmental factors. ${ }^{102}$

In response the pandisability approach borrows from the heuristic device of panethnicity; it allows otherwise heterogeneous groups to form a homogeneous class on the basis of a shared experience of prejudice, stereotyping and exclusion for the purposes of disparate impact litigation. However, it may be the case that the language of section 31 defies this type of argument: there must be a neutral provision which "puts persons of a particular disability" at a particular disadvantage compared with other employees of the employer. ${ }^{103}$ The critical issue will turn on how "persons of a particular disability" is interpreted. If interpreted strictly and literally, it may limit indirect discrimination claims to instances of "particular disadvantage" demonstrated only by individuals with similar impairments. ${ }^{104}$ It is interesting to consider whether the approach would be different if the statutory provision provided that the neutral provision would put "disabled people" at a particular disadvantage. Uncertainty remains as to how the term "persons of a particular disability" will be interpreted. It would be unsurprising if this aspect of the statutory provision were to be interpreted from a bio-medical perspective on disability which would demand that each member of the class of "individuals with disabilities" deviate from the perceived bodily norm in the same way. A broader, yet still medically inspired classification could be utilised, such as the approach taken in the statutory definition of disability. ${ }^{105} \mathrm{~A}$ more generalised categorisation system would support a social model perspective on disability and move away from the minutiae of individual impairments and medical labelling. This approach would embrace the pandisability analysis, as suggested by Stein and Waterstone above. It has the added advantage of focusing on the impact and effects of the practice, which denies groups of individuals employment opportunity, as opposed to the characteristics of the complainant, a focus that is unfortunately inverted in many jurisdictions with respect to the definition of disability. ${ }^{106}$ However, the likelihood of this broader interpretation must be considered against the backdrop of a consistent judicial deference to medical conceptions of disability. ${ }^{107}$

Aside from this issue, other barriers remain to a pandisability analysis of disparate impact claims under Irish law. The need to isolate a particular practice giving rise to the adverse impact is another hurdle which must be surmounted. In other words, it is simply insufficient to survey the demographic make-up of a particular place of employment pointing to a statistical absence of disabled people in relation to their presence in the available labour market: as Stein and Waterstone put it, there is little scope to argue that the environment generally is hostile to the presence of disabled people. ${ }^{108}$ Applicants must demonstrate the existence of a particular employment practice which causes the disparate

102 Waddington, Implementing and Interpreting, n. 7 above, at p. 82.

103 Given the range of impairments and their varying functional effects, some individual claimants may have "great difficulty in identifying a particular group that is disadvantaged by the relevant provision, criterion or practice in the same manner as they are": Whittle, "The Framework Directive", n. 7 above, at p. 308.

104 An ADA plaintiff may prove a disparate impact by demonstrating that an employer's policy "screens out or tends to screen out an individual with a disability or a class of individuals with disabilities". The plaintiff need not demonstrate an adverse effect on a class of persons with disabilities. See 42 USC s. 12112(b)(6).

105 See the definition of disability in s. 2(1) of the EEA 1998-2004.

106 Most notably the United States and the United Kingdom.

107 See generally, Parmet, "Plain meaning", n. 101 above. Note also the views of the Irish Supreme Court in Re Article 26 and the Employment Equality Bill 1996 [1997] 3 IR 321 and the ECJ in Chacon Navas v Colectividades [2007] ICR 1.

108 Stein and Waterstone, "Disability", n. 15 above, at p. 897. 
impact for disabled people. Where explicit formal practices are in operation, this task is less formidable - formal entry qualifications, promotion procedures etc. However, where a combination of informal norms and subjective practices collide, it becomes less easy to extract a specific practice or criterion as giving rise to the disparate impact. It may simply be a repetition of the inaccessibility of indirect discrimination norms to informal criteria that are often determinative of access to benefits and promotions in senior and professional positions on other grounds. This is where a disparate impact analysis of failure to accommodate can operate to tackle workplace culture and more hidden, subjective norms that combine to exclude disabled people from employment opportunities. ${ }^{109}$

\section{The relationship between reasonable accommodation and indirect discrimination at European level}

This part moves on to question the applicability of the pandisability argument to failure to accommodate and indirect discrimination at the level of the European Union. The key provision for consideration is Article 2(2)(b)(ii), which provides that a provision, criterion or practice will amount to indirect discrimination where

it would put persons having a particular disability ... at a particular disadvantage compared with other persons unless i) [it is] objectively justified by a legitimate aim, or (ii) as regards persons with a particular disability . . . the employer . . is obliged to [make a "reasonable accommodation"] in order to eliminate the disadvantages entailed by such provision, criterion or practice. ${ }^{110}$

This provision allows member states to choose to use the duty to make reasonable accommodation to remove the barriers and disadvantage caused by the indirectly discriminatory practice. This reading of Article 2(2)(b) suggests that, as long as the employer provides a reasonable accommodation to a disabled employee/applicant, the employer will be entitled to maintain the provision that puts disabled people more generally at a particular disadvantage. Thus, an employer can continue to apply the indirectly discriminatory practice against the group, as long as the employer offsets the disadvantage accruing to the specific individual with a disability by way of a reasonable accommodation. ${ }^{111}$ This aspect of the directive is problematic and is an attack on the scope and potential of the indirect discrimination principle in the disability context. As Whittle comments, its effect "is to remove any group benefits that may have otherwise accrued from a successful action in this regard". 112 This approach upsets the orthodox practice of requiring the policy to be changed for the benefit of all, though in the disability context the possibility of a multitude of employment practices giving rise to disparate impact on the grounds of disability may be one of the reasons for the original introduction of the

109 Discussed further in Stein and Waterstone, "Disability", n. 15 above, at pp. 917-20.

110 Art. 2(2)(b)(ii) of the Equality Directive.

$111 \mathrm{It}$ is worth noting that the procedural operation of the accommodation duty in some jurisdictions also weakens the section's provision for indirect discrimination. Under the UK's DDA 1995-2005, the duty becomes operable following a request from a covered individual. As Bamforth et al. point out, the requirement to refrain from indirect discrimination could require action even in the absence of a specific accommodation request: N Bamforth, M Malik and C O'Cinneide, Discrimination Law: Theory and context (London: Sweet \& Maxwell 2008), p. 1006.

112 Whittle, "The Framework Directive", n. 7 above, at p. 310. 
provision. ${ }^{113}$ More broadly, as De Schutter points out, these "[a]d-hoc, individualised compensation measures risk becoming substitutes for wider scale modifications especially in the built environment or the organisation of work". ${ }^{114}$ Under the EC structure, the individualised reasonable accommodation provision could allow the continuation of instances of indirect discrimination against groups of disabled people more generally. Not all member states have opted to implement the accommodation duty in substitution for the indirect discrimination principle.

Notwithstanding this point, the elements hostile to a disparate impact analysis of failure to accommodate claims have already been highlighted using the example of Ireland's equality legislation, which includes a stand-alone indirect disability discrimination provision. Further, given the absence of the orthodox elements of indirect discrimination under the Framework Directive, the suggestion by Stein and Waterstone of a disparate impact analysis of failure to accommodate claims across a wider range of sub-groups of disabled people also appears foreclosed.

\section{Conclusion}

The essence of the pandisability argument is that failure to accommodate claims can be analysed in ways beyond the current atomistic, individualistic approach. A more potent approach recognises that the failure to accommodate claims may not only affect the individual requester, but potentially illustrates the existence of employment practices and procedures which disproportionately exclude groups of disabled people from employment practices. In other words, the indirect discrimination analysis appears applicable to the reasonable accommodation duty because the failure to accommodate cases may have an impact beyond the specific circumstances of the individual with a disability and raise questions as to what extent such practices adversely impact groups of disabled people.

While such an interpretation of the reasonable accommodation duty may be raised in principle, real practical barriers remain. Interpreting the reasonable accommodation duty from an indirect discrimination perspective seems to have been closed off in two distinct ways. First, there are real doubts about the ability of the indirect discrimination norm to reconstruct institutions and practices in as inclusive a manner as possible - in essence, the pandisability argument simply overloads an already burdened discrimination norm with the impossible job of transforming more widely indirectly discriminatory practices which impact on groups of disabled people. This argument is predicated on the ability of indirect discrimination norms to promote transformative, pre-emptive practices on the part of employers by means of encouraging them to assess existing employment practices for possible disparate impact. However, this analysis is simply overstated. Except in the aftermath of the Dred Scott era and the period immediately after the Griggs decision in the US, employers, particularly, private sector employers, have rarely been involved in wholescale policy and procedure review from a disparate impact perspective. It does not demand any radical restructuring of employers' practices which remain justifiable. Second, despite the advance inherent in the notion of pandisability, there are barriers to surmount in respect of the constituent elements of the statutory definition of indirect discrimination

113 Tobler notes that "Art.2(2)(b)(ii) is intended to reinforce the duty to provide reasonable accommodation, in that the alleged discriminator can rebut a presumption of indirect discrimination by pointing to reasonable accommodation ... Seen in this way, the consequence . . . is to help the victims of the alleged indirect discrimination to obtain reasonable accommodation, whilst giving the employer a certain degree of flexibility.": Limits and Potential, n. 8 above, at V.5.

114 O De Schutter, "Reasonable accommodations and positive obligations" in C Gooding and A Lawson (eds), Disability Equality in Europe from Theory to Practice (Oxford: Hart Publishing 2005), p. 35, at p.63. 
as discussed above. Further, even if it were possible to surmount the possible statutory barriers raised above, one issue which has so far been overlooked is that a prima facie case of indirect discrimination always remains justifiable. ${ }^{115}$ One of the major downfalls of the indirect discrimination principle has been its poor relation to the employer's interests in continuing with the practice or policy giving rise to disparate impact: in other words, it may often cede to powerful and established institutional rules that reflect the way things have always been done. ${ }^{116}$ In light of these difficulties, Ellis has described indirect discrimination as "essentially ... non-dynamic and [non]-redistributive . . . because it does little to dismantle hidden obstacles facing protected groups" or to "change customarily stereotyped roles". ${ }^{117}$ Thus, both indirect discrimination and reasonable accommodation have their own separate limitations and their own spheres of operation. As such, the attempt to infuse new life into these doctrines may be little more than an elaborate discussion that repeats and reasserts many of the pre-existing limitations that attach to their interpretation and application in the struggle for disability equality.

115 See Bilka-Kaufhaus GmBh v Weber Von Hartz Case 170/84 [1986] ECR 160.

116 Though note the more robust enquiry into the employer's justification demanded by the proportionality principle.

117 Ellis, EU Anti-Discrimination Law, n. 92 above, at p. 115. 